PRINT ISSN 1119-8362

Electronic ISSN 1119-8362
Full-text Available Online at https://www.ajol.info/index.php/jasem http://ww.bioline.org.br/ja
J. Appl. Sci. Environ. Manage.

Vol. 25 (9) 1575-1580 September 2021

\title{
EDTA and Nitric Acid Responses on Nickel Uptake, Translocation Factor and Pigments on Spinacia oleracea L. Replanted Seedlings in Hydroponic Solution
}

\author{
*ABDULSALAM, S; YAHAYA, MK; HABIB, LO; UGBENYO, NO
}

Department of Chemistry, Confluence University of Science and Technology, Osara, Kogi State. Nigeria

*Corresponding author Email: abdulsalams@custech.edu.ng; Tel: +2347038359776

\begin{abstract}
The effects of $\mathrm{Na}_{2} \mathrm{EDTA}$ and $\mathrm{HNO}_{3}$ on $\mathrm{Ni}^{2+}$ uptake by Spinacia oleracea seedlings replanted in hydroponic culture in a greenhouse was investigated. Eight week old seedlings, were exposed to various doses of $\mathrm{Ni}^{2+}$ $(0,1000,2000$, and $4000 \mathrm{mg} / \mathrm{L})$ as $\mathrm{NiSO}_{4}$, at $(0,500$ and $3000 \mathrm{mg} / \mathrm{L}) \mathrm{Na}_{2}$ EDTA and $(0,500$ and $3000 \mathrm{mg} / \mathrm{L}) \mathrm{HNO}_{3}$ in different combinations. There was a substantial increase in nickel uptake in chelated treatments $(\mathrm{p}<0.05)$ compared to unchelated treatments of same concentrations of $\mathrm{Ni}^{2+}$. So, chelation enhanced $\mathrm{Ni}^{2+}$ uptake in S. oleracea. During the exposure, antioxidant defense system helped the plant to protect itself from the damage. Due to increasing nickel uptake by the plant, the photosynthetic pigments (i.e chlorophyll a, chlorophyll $\mathrm{b}$ and Caretenoids) gradually declined. In this study, Spinacia oleracea Seedlings and contents of the photosynthetic pigments (chlorophyll a, chlorophyll b and Caretenoids) of both chelated and unchelated hydroponic treatments were investigated. Changes in photosynthetic pigments was significant $(\mathrm{p}<0.05)$ with respect to addition of EDTA and $\mathrm{HNO}_{3}$ at different concentration to different concentrations of $\mathrm{Ni}^{2+}$ compared to unchelated treatments of same concentrations of $\mathrm{Ni}^{2+}$. The $\mathrm{Ni}^{2+}$ induced translocation factor was also determined which increased significantly $(\mathrm{P}<0.05)$ with increasing $\mathrm{Ni}^{2+}$ concentrations.
\end{abstract}

\section{DOI:https://dx.doi.org/10.4314/jasem.v25i9.5}

Copyright: Copyright (C) 2021 Abdulsalam et al. This is an open access article distributed under the Creative Commons Attribution License (CCL), which permits unrestricted use, distribution, and reproduction in any medium, provided the original work is properly cited.

Dates: Received: 09 May 2021; Revised: 12 August 2021; Accepted: 12 September 2021

Keywords: Nickel, Translocation Factor, Hydroponic, EDTA, Nitric acid, Spinacia oleracea, Pigment.

Wastewater from many sources, including industries, kitchen sinks and mining sites has been found to contain traces of nickel (Carocci et al., 2016). Tobacco smoking is linked to nickel sources as research reveals that each cigarette contains a nickel amount of 1.1 $3.1 \mu \mathrm{g}$; present as nickel carbonyl (Genchi et al., 2020). The most stable states of nickel in the environment is the +2 oxidation state $\left(\mathrm{Ni}^{+2}\right)$, other valences include $-1,0,+3$ and +4 . Natural sources of nickel include dust, mass creeping of rocks, volcanic eruptions and soil. Nickel exposure can be through dietry intake of some vegetables such as spinach, carrot, green beans and tomato (Carocci et al., 2016). Human exposure to highly nickel-concentrated environments may cause a variety of health effects. Accumulation of nickel and nickel compounds in the body through chronic exposure may be responsible for some of these deadly diseases to human beings, such as kidney failure, lung fibrosis, cardiovascular diseases and cancer of the respiratory tract. Nickel is essential for plant in low concentration but high concentration is toxic. Nickel is naturally occurring in soil and surface water with concentration lower than 100 and 0.005 ppm, respectively (Chen et al., 2009). Nickel is an essential micronutrient for some higher plants, it acts as enzyme co-factor and is beneficial for plants in trace quantities, but higher concentrations pose toxic effects to plant growth. High nickel levels in plants reduce the rate of metabolic activities and decrease water and nutrient uptake in plants (Younis et al., 2015). This research is a demonstration of the extent of damage caused and the stress level undergo by Spinacia oleracea Seedlings under nickel toxicity for a particular treatment and the effects of various doses of $\mathrm{Na}_{2}$ EDTA on nickel at it stable form. Ethelene diamine tetra acetic acid (EDTA) is a multidentate ligand which when donate its lone pair of electrons to a central metal ion such as $\mathrm{Ni}^{+2}$ to form a chelate. Chelating agents can react with metal ions and influence metal phytotoxicity and phytoextraction (Hassan et al., 2020). EDTA is often used to enhance metal uptake by plants in field and some hydroponic experiments (Zhou et al., 2020). Also, chelating agents helps in translocating metal from roots to shoot system of plants (Chen et al., 2020). Chlorides within its permissible limit by WHO is used in water purification in Nigeria, with this; different chloride concentrations are often present in aquatic environments. Chloride can increase metal solubility, which may enhance metal bioaccumulation in shoots and roots of plants; however, only a few studies have been conducted on the effects of chloride on nickel (He et al., 2020). Studies on the effects of chloride on $\mathrm{Ni}$ phytoremediation are also limited. 


\section{MATERIALS AND METHODS}

Hydroponic Culture: Eight week old S. oleracea seedlings were carefully collected from Department of Agronomy farm, Bayero University, Kano. The seeds of $S$. oleracea were sterilized in a $10 \% \mathrm{H}_{2} \mathrm{O}_{2}$ solution for $15 \mathrm{~min}$ and then washed with distilled water before they were soaked in distilled water for 8 hours at $50^{\circ} \mathrm{C}$ and were sown on artificially. The seeds germinated at room temperature in a greenhouse at $65 \%$ relative humidity, 13 hour light/11 hour dark photoperiod (photosynthetically active radiation $600 \mu \mathrm{mol} \mathrm{m}^{-2} \mathrm{~s}^{-1}$ with day/night temperatures $39 / 23^{\circ} \mathrm{C}$ ). Each plants were supplied with $300 \mathrm{ml}$ modified Hoagland nutrient solution with $\mathrm{pH}(1.57$ - 6.82). After five days of exposure, the roots were extracted carefully after germination. Roots and shoots of similar size were selected, dried at room temperature for two weeks and then placed in a dark polythene bag for further analysis. Translocation Factor (TF) was calculated as reported by Yoon et al. (2006).

$$
\mathrm{TF}=\frac{\mathrm{Ni} 2+\text { content of shoot }}{\mathrm{Ni} 2+\text { content } \text { of root }} \times 100
$$

AAS determination of $\mathrm{Ni}$ was carried out after the roots and shoots were prepared using mixed acid $\left(\mathrm{HNO}_{3} / \mathrm{HCl}\right)$ as carried out by Adolfo et al. (2020).

Determination of Pigment Content (Chlorophyll A, Chlorophyll $B$ and Caratenoid): The estimation of pigments content in both control and treated plants were carried out according to the method of Gitelson (2020). $2.0 \mathrm{~g}$ of dried leaf tissue of each sample were homogenized using $80 \%$ acetone. The homogenates was centrifuged for 10 minutes and the supernatant was collected. The residue was again extracted and the supernatant was pooled together. The extraction process was repeated until the residue became colourless. The volume of the combined supernatant was recorded. The absorbance of solution was then measured at $645 \mathrm{~nm}, 663 \mathrm{~nm}$ and $470 \mathrm{~nm}$ for both Chlorophyll A, Chlorophyll B and Caratenoid respectively using a UV -visible spectrophotometer.

The amount of Chlorophyll A, B and Caretenoid were calculated using the relation:

$$
\begin{gathered}
\text { Chlorophyll A }\left(\mathrm{mg} \mathrm{g}^{-1}\right)=[(11.75 \times \text { A663) }-(2.350 \times \\
\text { A645)] } \times \text { Vol. of acetone } \\
\text { Chlorophyll B }\left(\mathrm{mg} \mathrm{g}^{-1}\right)=[(18.61 \times \text { A645) }-(3.960 \times \\
\text { A663) }] \times \text { Vol. of acetone }
\end{gathered}
$$

$$
\begin{aligned}
& \text { Carat } \\
& =\frac{1000 \text { A470 - 2.270 Chloro A }-81.4 \text { Chloro B }}{227}
\end{aligned}
$$

Where Carat $=$ Caratenoid; Chlor $\mathrm{A}=$ Chlorophyll A and Chloro B = Chlorophyl B

Statistical Analysis: All data presented in this study are the mean values of three replicates. Statistical analysis was performed using Excel 2010 software and significance test were performed using One-way ANOVA at $95 \%$ confidence level.

\section{RESULTS AND DISCUSSION}

Nickel content in Spinacia oleracea Seedlings: Nickel concentration in roots and shoots of spinach plants were significantly increased $(\mathrm{p}<0.05)$ when plants were exposed to nickel at varied concentration $(0$, 1000, 2000 and $4000 \mathrm{mg} / \mathrm{L})$ relative to control plants. Nickel concentration in roots and shoots gradually increased with increasing nickel concentration in the hydroponic treatments. The root accumulated the largest in all treatment. Application of EDTA and $\mathrm{HNO}_{3}$ at constant concentration $(500 \mathrm{mg} / \mathrm{L})$ in Fig 3.1A significantly increased $(\mathrm{p}<0.05)$ the nickel concentration in roots and shoots as compared to treatment without EDTA and $\mathrm{HNO}_{3}$. The highest uptake of $\mathrm{Ni}^{2+}$ was observed in Fig 3.1C when concentration of EDTA and $\mathrm{HNO}_{3}$ was raised to $3000 \mathrm{mg} / \mathrm{L}$. The effect of $\mathrm{Na}_{2}$ EDTA and $\mathrm{HNO}_{3}$ was visible between $24-48$ hours. Some of the prominent symptoms were bleaching of leaf margin, chlorosis in leaves, browning of root tips and broken off roots indicating phytotoxicity.

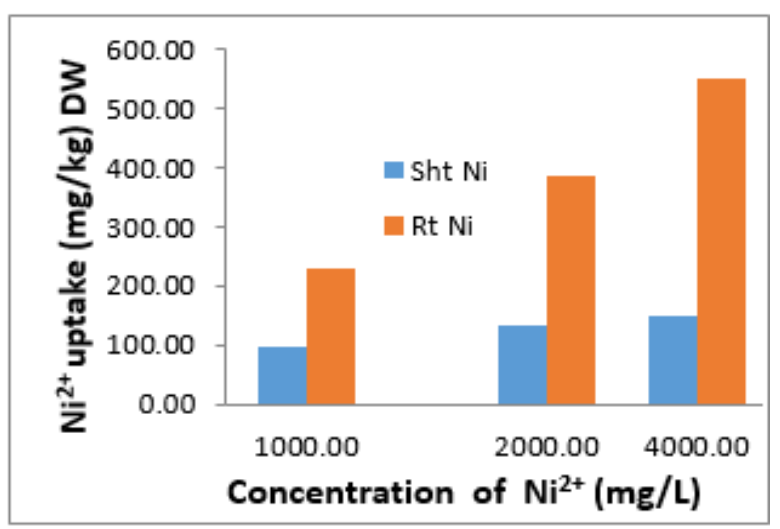

Fig 3.1: Effect of addition of $0 \mathrm{mg} / \mathrm{L} \mathrm{HNO}_{3}$ on Absorption of $\mathrm{Ni}^{2+}$ by $S$. oleracea Seedlings replanted in Hydroponic mixture at $0 \mathrm{mg} / \mathrm{L}$ $\mathrm{Na}_{2}$ EDTA.

Translocation factor of $\mathrm{Ni}^{2+}$ in S. oleracea Seedlings: Translocation factor (TF) is the capacity of a plant to transfer metal from its roots to shoots. The TF of $S$. oleracea plant significantly decreased $(\mathrm{p}<0.05)$ when the plant was exposed to nickel at varied concentration $(0,1000,2000$ and 4000mg/l). At $0 \mathrm{mg} / \mathrm{L} \mathrm{Na} 2$ EDTA and $\mathrm{HNO}_{3}$, the TF gradually increases as $\mathrm{Ni}$ concentration increased from 0 to $1000 \mathrm{mg} / \mathrm{l}$ and 
slightly decreases as $\mathrm{Ni}$ concentration increases to 2000 and $4000 \mathrm{mg} / \mathrm{l}$ respectively. This is in conformity with the work of Yoon et al. (2006). Fig 3.2 shows the translocation factor of $\mathrm{Ni}$ by the $\mathrm{S}$. oleracea seedlings. Similar trend was observed when $\mathrm{Na}_{2}$ EDTA and $\mathrm{HNO}_{3}$ concentrations was raised to $500 \mathrm{mg} / \mathrm{L}$ and $3000 \mathrm{mg} / \mathrm{L}$ respectively.

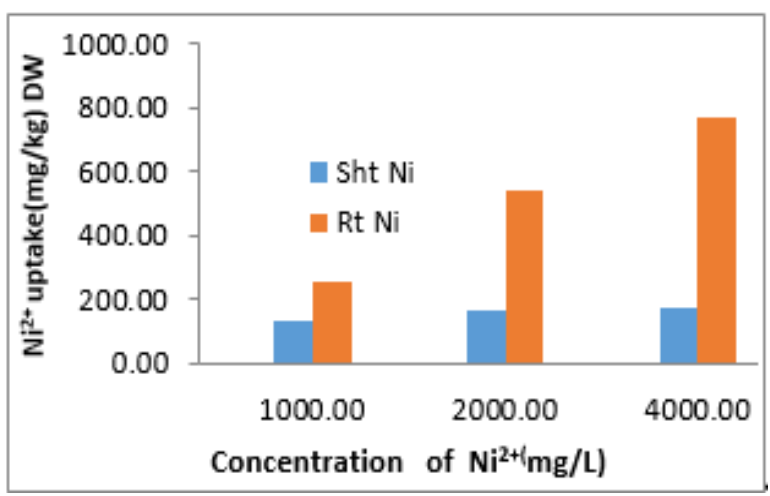

Fig 3.1B: Effect of addition of $500 \mathrm{mg} / \mathrm{L} \mathrm{HNO}_{3}$ on Absorption of $\mathrm{Ni}^{2+}$ by $S$. oleracea replanted in Hydroponic mixture at $500 \mathrm{mg} / \mathrm{L}$ $\mathrm{Na}_{2}$ EDTA

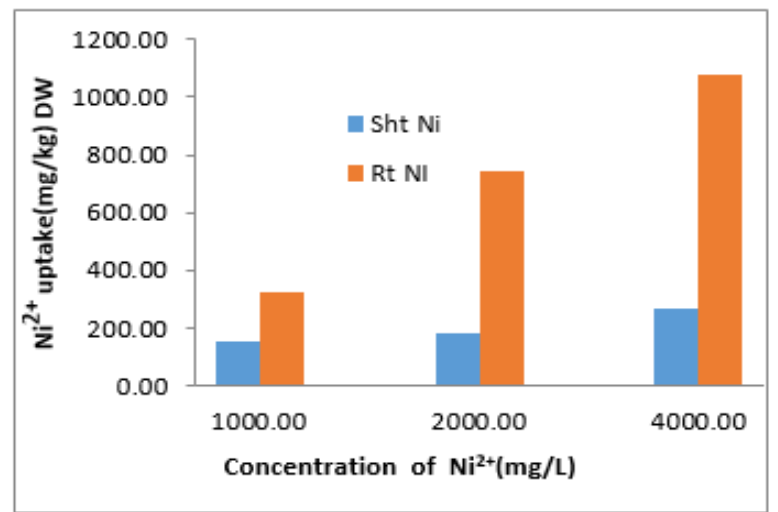

Fig 3.1C: Effect of addition of $3000 \mathrm{mg} / \mathrm{L} \mathrm{HNO}_{3}$ on Absorption of $\mathrm{Ni}^{2+}$ by $\mathrm{S}$. oleracea Seedlings replanted in Hydroponic mixture at $3000 \mathrm{mg} / \mathrm{L} \mathrm{Na} 2$ EDTA.

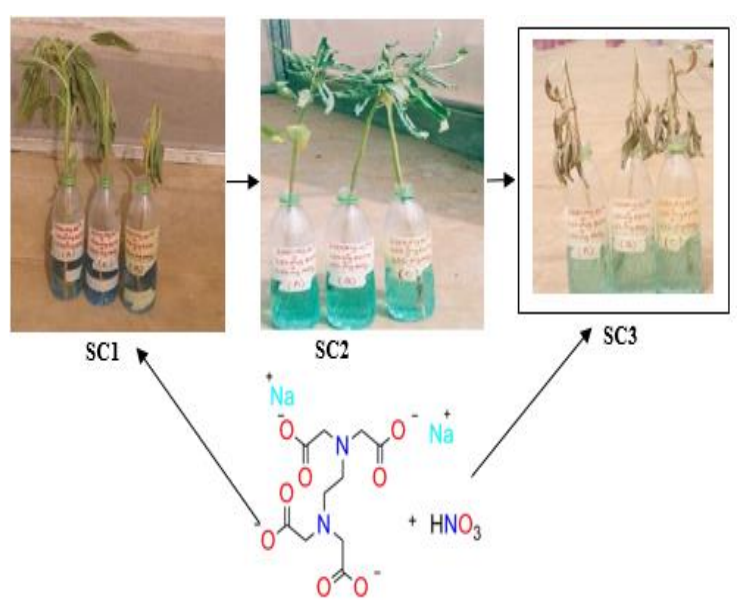

Plate 1: $\mathrm{SC} 1-\mathrm{SC} 3$ : Shows effect of $\mathrm{Na}_{2} \mathrm{EDTA}$ and $\mathrm{HNO}_{3}$ after 24 hours

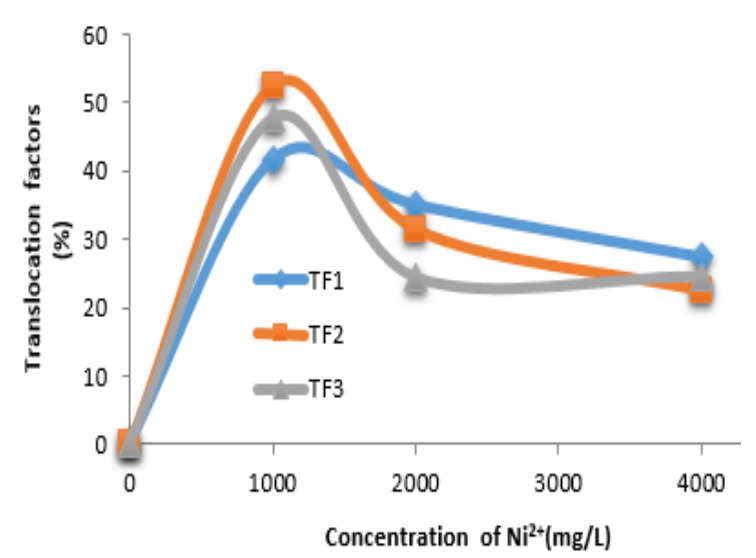

Fig 3.2: Effect of $\mathrm{HNO}_{3}$ and $\mathrm{Na}_{2} \mathrm{EDTA}$, on $\mathrm{Ni}^{2+} \mathrm{TF}$ in $S$. oleracea Seedlings replanted in hydroponic solution

KEY: TF1: $T F$ at $0 \mathrm{mg} / \mathrm{L}$ each $\mathrm{HNO}_{3}$ and $\mathrm{Na}_{2} E D T A$, TF2: $T F$ at $500 \mathrm{mg} / \mathrm{L}$ each of $\mathrm{HNO}_{3}$ and $\mathrm{Na}_{2} \mathrm{EDTA}$ and TF3: TF at $3000 \mathrm{mg} / \mathrm{L}$ each of $\mathrm{HNO}_{3}$ and $\mathrm{Na}_{2} E D T A$.

Pigment Content of S. oleracea Seedlings: The plant pigments chlorophyll A, chlorophyll B and carotenoids were determined to justify the $\mathrm{Ni}^{2+}$ uptake by the plants. The results revealed inverse proportion of $\mathrm{Ni}^{2+}$ uptake significantly $(p<0.05)$ for chlorophyll A, chlorophyll B and carotenoids contents. Figure 3.3A shows the pigment content of Spinach seedlings in the absence of $\mathrm{Na}_{2}$ EDTA and $\mathrm{HNO}_{3}$. The plants were exposed to nickel at varied concentration $(0$, 1000, 2000 and $4000 \mathrm{mg} / \mathrm{L}$. Pigment contents in shoots gradually decreases with increasing nickel concentration in the hydroponic treatments. Application of $\mathrm{Na}_{2} \mathrm{EDTA}$ and $\mathrm{HNO}_{3}$ at constant concentration $(500 \mathrm{mg} / \mathrm{L})$ in Figure 3.3B significantly decreased $(\mathrm{p}<0.05)$ the pigment contents as compared to treatment without $\mathrm{Na}_{2}$ EDTA and $\mathrm{HNO}_{3}$. Similar trend was observed in Figure 3.3C when concentration of $\mathrm{Na}_{2} \mathrm{EDTA}$ and $\mathrm{HNO}_{3}$ was raised to $3000 \mathrm{mg} / \mathrm{L}$.

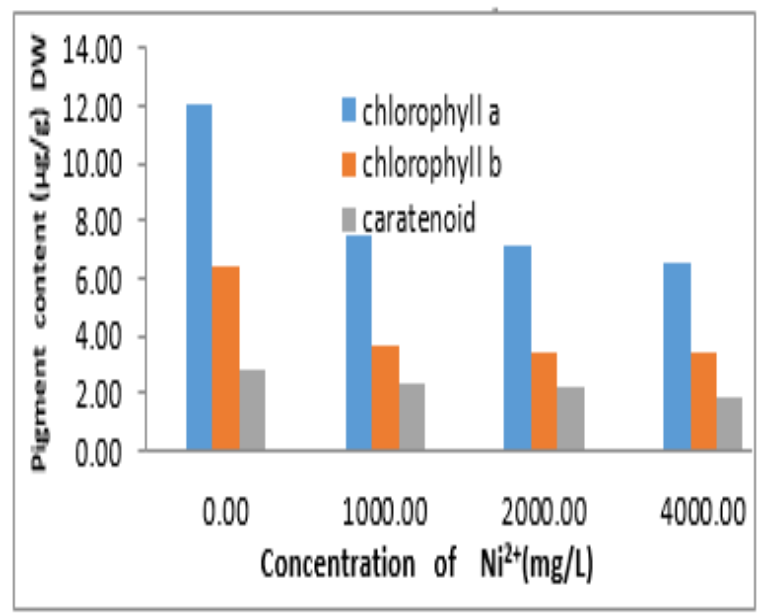

Figure 3.3A: Effect of addition of $0 \mathrm{mg} / \mathrm{L} \mathrm{HNO}_{3}$ on pigment content of $S$. oleracea seedlings replanted in hydroponic mixture at $0 \mathrm{mg} / \mathrm{L} \mathrm{Na}{ }_{2}$ EDTA 


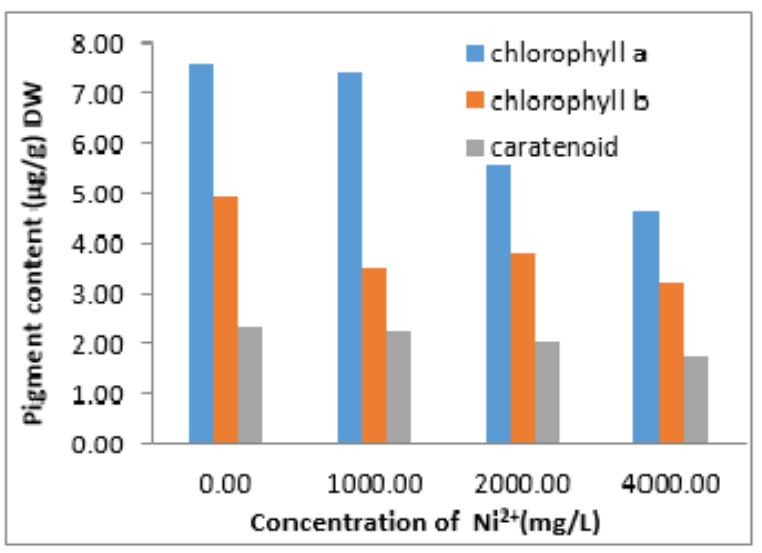

Fig 3.3B: Effect of $500 \mathrm{mg} / \mathrm{L}$ each of $\mathrm{Na}_{2} \mathrm{EDTA}$ and $\mathrm{HNO}_{3}$ on pigment content of $S$. oleracea seedlings replanted in hydroponic mixture

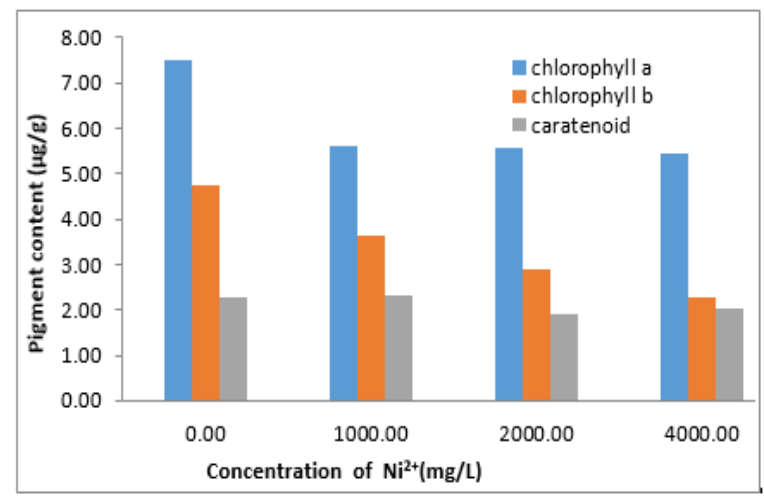

Figure 3.3C: Effect of $3000 \mathrm{mg} / \mathrm{L}$ each of $\mathrm{Na}_{2} \mathrm{EDTA}$ and $\mathrm{HNO}_{3}$ on pigment content of $S$. oleracea seedlings replanted in hydroponic mixture

Nickel stresses uptake: Nickel is an essential micronutrient for some higher plants (Younis et al., 2015). It acts as a co-factor of enzymes and it's beneficial for animals in trace quantities, but its higher concentrations pose toxic effects in plant growth. High nickel levels in plants reduce the rate of metabolic activities and decrease water and nutrient uptake in plants (Gajewaska et al., 2006). Nickel at low levels are important for plant growth, plant senescence, nitrogen metabolism, seed germination and plant disease resistance (Hussain et al 2013). However, Ni can be phytotoxic when soluble forms of $\mathrm{Ni}$ are present in soil in excess. Furthermore, some physiological and biochemical parameters were also considered to buttress the results. In this study the spinach (Spinacia oleracea L.) seedlings were exposed to various doses of $\mathrm{Ni}^{2+}(0,1000,2000$, and 4000 $\mathrm{mg} / \mathrm{L})$ supplied as $\mathrm{NiSO}_{4}$, EDTA $(0,500$, and 3000 $\mathrm{mg} / \mathrm{L})$ supplied as $\mathrm{Na}_{2}$ EDTA and $\mathrm{HNO}_{3}(0,500$, and $3000 \mathrm{mg} / \mathrm{L}$ ) in the nutrient solution. The results of both chelate-assisted and unchelated hydroponic treatments revealed significant changes $(\mathrm{p}<0.05)$ in $\mathrm{Ni}^{2+}$ uptake by the plant.
The results of unchelated hydroponic treatments are supported by Saleh (2002) and Giordan et al (2005), they reported that the roots accumulate the largest $\mathrm{Ni}^{2+}$ concentration. Increase in soil solution concentration of $\mathrm{Ni}$ resulted in increased $\mathrm{Ni}$ concentration in plant tissues. The highest root uptake in unchelated hydroponic treatment was $(549.87 \mathrm{mg} / \mathrm{kg} \pm 0.72)$ at $4000 \mathrm{mg} / \mathrm{L}$.At the application of 500 and 3000 mg/Leach of EDTA and $\mathrm{HNO}_{3}$ to various doses of nickel in the hydroponic solution significantly increased $(p<0.05)$ the uptake of nickel compared to unchelated hydroponic treatments of same concentrations of $\mathrm{Ni}^{2+}$. The root uptake in the chelated hydroponic treatments were 1.346 and 1.960 times higher than the unchelated hydroponic treatments at $4000 \mathrm{mg} / \mathrm{L} \mathrm{Ni}{ }^{2+}$ concentrations. So, chelation enhanced $\mathrm{Ni}^{2+}$ uptake by $\mathrm{S}$. oleracea. The highest root uptake in chelated hydroponic treatments was $1077.46 \mathrm{mg} / \mathrm{kg} \pm 0.54$ at $4000 \mathrm{mg} / \mathrm{L}+30000 \mathrm{mg} / \mathrm{L}$ EDTA $+3000 \mathrm{mg} / \mathrm{L} \mathrm{HNO}_{3}(\mathrm{p}<0.05)$. Jean et al. (2008) and Jing et al. (2015) findings both suggested that EDTA is the most effective means of increasing the uptake of Ni in plants. Chaney et al. (1998) proposed that EDTA and nitrilotriacetic acid (NTA) can increase bioavailability of nickel and other Elements. Many phytoextraction studies have been carried out using synthetic chelates such as EDTA and NTA in order to artificially enhance metals solubility, resulting in a marked increase in metal uptake by plants (Johnson et al., 2009). According to Chen et al (2010), EDTA-promoted uptake of $\mathrm{Cr}$ in Ipomonea aquatic. From the result above the root accumulated the highest $\mathrm{Ni}$ content therefore it is probable that the formation of $\mathrm{Ni}$-EDTA enhanced the mass transfer of $\mathrm{Ni}^{2+}$ ions to the root surface. Addition of varying amount of $\mathrm{HNO}_{3}$ and $\mathrm{Na}_{2}$ EDTA decreased the $\mathrm{pH}$ significantly before and after harvest which facilitated the absorption of sufficient quantities of $\mathrm{Ni}^{2+}$ by the plant. Acidic $\mathrm{pH}$ increases the absorption of nickel in soil Zarkovic and Srdjan (2009). The plants were harvested at different times as they died. The control plants were the last to die. Those in other treatment died much earlier due to phytotoxicity effect of nickel. Nickel also induces visible toxicity in S. oleracea. The general symptoms of nickel toxicity were bleaching of leaf margin, chlorosis in leaves, browning of root tips and broken off roots. The toxicity symptoms in plants could be attributed to high accumulation of nickel in tissues (Saleh, 2002). It has been reported that nickel ion decrease the permeability of cell membrane inhibit root system development and cause necrosis and chlorosis (Pandey and Gautam, 2009).

The TF factor: TF decreased significantly $(\mathrm{p}<0.05)$ with increasing concentration of added $\mathrm{Ni}^{2+}$. Thus, a small fraction of the $\mathrm{Ni}^{2+}$ was translocated to the 
shoots at $0 \mathrm{mg} / \mathrm{L}$ each of $\mathrm{HNO}_{3}$ and EDTA $(41.71 \%, 35.01 \%, 27.36 \%)$ at $500 \mathrm{mg} / \mathrm{L}$ each of $\mathrm{HNO}_{3}$ and EDTA $(52.59 \%, 31.48 \%, 22.47 \%)$ at $3000 \mathrm{mg} / \mathrm{L}$ each of $\mathrm{HNO}_{3}$ and $\operatorname{EDTA}(47.80 \%, 24.32 \%, 24.46 \%)$. The highest TF of unchelated hydroponic treatment was $41.71 \pm 0.27 \%$ at $1000 \mathrm{mg} / \mathrm{l}$ while the chelated hydroponics treatment was $52.59 \pm 0.10 \%$ at $1000 \mathrm{mg} / \mathrm{L}$ $+500 \mathrm{mg} / \mathrm{L} \mathrm{EDTA}+500 \mathrm{mg} / \mathrm{L} \mathrm{HNO}_{3}$. From the results above EDTA aid the translocation of $\mathrm{Ni}^{2+}$ from the roots to the shoots of spinach Seedlings but most of the $\mathrm{Ni}^{2+}$ was retained in the roots. This observation is in agreement with the report of Lombi et al (2001) who observed that EDTA application increased metal mobility in soil and uptake by roots, but did not substantially increase the transfer of metals $(\mathrm{Cd}, \mathrm{Zn}$, $\mathrm{Pb}, \mathrm{Cu})$ to corn shoots. For that, they suggested that EDTA was far more efficient in overcoming the diffusion limitation of metals to the root surface than the barrier of root to shoot translocation.

Effect of Pigment: The chlorophyll A, chlorophyll B, and carotenoid content decreased substantially with increasing $\mathrm{Ni}^{2+}$ concentrations $(P<0.05)$. The photosynthetic contents in unchelated hydroponic treatments were relatively higher than those in chelated treatments of same $\mathrm{Ni}^{2+}$ concentrations. The chelated hydroponic treatments showed the highest decrease of Chlorophylls A $4.68 \mu \mathrm{g} / \mathrm{g} \pm 0.24$ Chlorophylls B $3.24 \mu \mathrm{g} / \mathrm{g} \pm 0.010$ and caretenoids $1.75 \mu \mathrm{g} / \mathrm{g} \pm 0.001$ at $4000 \mathrm{mg} / \mathrm{L} \mathrm{Ni}^{2+}+500 \mathrm{mg} / \mathrm{L}$ EDTA $+500 \mathrm{mg} / \mathrm{L} \mathrm{HNO}_{3}$ when compared to unchelated hydroponic treatment Chlorophylls A $6.64 \mu \mathrm{g} / \mathrm{g} \pm 0.11$ Chlorophylls B 3.46. $\mu \mathrm{g} / \mathrm{g} \pm 0.08$ and carotenoids $1.92 \mu \mathrm{g} / \mathrm{g} \pm 0.03$ at $4000 \mathrm{mg} / \mathrm{L} \mathrm{Ni}{ }^{2+}$. Similar findings were reported by Pandey and Sharma (2002), who reported that concentration of chlorophyll a was more reduced than that of chlorophyll $b$ in leaves of nickel treated cabbage. Vajpayee et al (2001) also reported greater inhibition in chlorophyll a than chlorophyll $b$ following exposure to heavy metal $(\mathrm{Cr})$ in submerged aquatic plants. Nickel inhibits chlorophyll biosynthesis by creating nutrient imbalances, replacement of $\mathrm{Mg}^{2+}$ ions (Molas, 2002). The decrease in photosynthetic pigments is due to the inhibition of the activities of enzyme that play important roles in the synthesis of these pigments, such as $\delta$-aminolevulinic acid dehydratase and proto-chlorophylli-dereductase (Younis et al., 2015).

Conclusion: The effect of nickel stresses were investigated and the results clearly indicated that application of various doses of $\mathrm{Ni}^{2+}$ to hydroponic solution enhanced the phytoextraction of $\mathrm{Ni}^{2+}$ in Spinach (Spinacia Oleracea) Seedlings. The different levels of nickel had negative effects on growth, chlorophylls A, B, and caratenoid and physiological attributes of Spinach plants.

\section{REFERENCE}

Adolfo, FR., do Nascimento, PC, Leal, GC, Bohrer, D., Viana, C., and de Carvalho, LM. (2020). Simultaneous determination of $\mathrm{Fe}$ and $\mathrm{Ni}$ in guarana (Paullinia cupana Kunth) by HR-CS GF AAS: Comparison of direct solid analysis and wet acid digestion procedures. J. Food Comp. and Analy. 88, 103459 .

Carocci, A.; Catalano, A.; Lauria, G.; Sinicropi, MS.; Genchi, G. (2016). A review on mercury toxicity in food. In Food Toxicology; Debasis, B., Anand, S., Stohs, S.J., Eds.; CRC Press: Boca Raton, FL, USA; Chapter 16; pp. 315-326.

Chaney, RL, Angle, RS, Baker, AJM, Li, YM. (1998). Method for phytomining of nickel cobalt and other metals from soil. U.S. Patent 5711784.

Chen, C., Huang, D. and Liu, J. (2009). Functions and Toxicity of Nickel in Plants A Review: Recent Advances and Future Prospects. Clean, 37 (4), $304-$ 313.

Chen, JC, Wang, KS, Chen. H., Lu, CY.,Huang. LC, Li, HC. (2010). Phytoremediation of $\mathrm{Cr}$ (III) by Ipomonea aquatica (water spinach) from water in the presence of EDTA and chloride: Effects of $\mathrm{Cr}$ speciation. Bio Res. Tech. 101(9): 3033-3039.

Chen, L., Yang, JY, Wang, D. (2020). Phytoremediation of uranium and cadmium contaminated soils by sunflower (Helianthus annuus L.) enhanced with biodegradable chelating agents. $J$. of Cleaner Prod., 263, 121491.

Gajewska, E., Sklodowska, M., Slaba, M., Mazur, J. (2006). Effect of nickel on antioxidative enzyme activities, proline and chlorophyll content in wheat shoots. Bio. Plant. 50(4):653-659.

Genchi, G., Carocci, A., Lauria, G., Sinicropi, MS., and Catalano, A. (2020). Nickel: Human health and environmental toxicology. Inter. J. of environ. Research and pub. Health. 17(3), 679.

Hassan, A., Mahmoud, M., Bageri, BS, Aljawad, MS., Kamal, MS., Barri, AA., and Hussein, IA. (2020). Applications of chelating agents in the upstream oil and gas industry: a review. Energy and Fuels, 34(12), 15593-15613.

Hussain, MB, Shafaqa, TA, Aqeel, A., Saadia, H., Muhammad, AF, Basharat, A., Saima, AB and Muhammad, BG. (2013). Morphological, physiological and biochemical responses of plants to 
nickel stress: A review. Afri. J. of Agri. Res.8 (17)1596-1602.

He, D., Zeng, L., Zhang, G., Guan, W., Cao, Z., Li, Q., and $\mathrm{Wu}, \mathrm{S}$. (2020). Extraction behavior and mechanism of nickel in chloride solution using a cleaner extractant. J. of Cleaner Prod., 242, 118517.

Gitelson, A. (2020). Towards a generic approach to remote non-invasive estimation of foliar carotenoidto-chlorophyll ratio. J. of Plant Physio., 252, 153227

Jean, L., Bordas, F., Gautier-Moussard, C., Vernay, P. (2008). Effect of citric acid and EDTA on chromium and nickel uptake and translocation by Datura innoxia. Environ. Pollution, 153(3):555-563.

Jing, N., Yuqiang, P., Jing, S.,Yan, G., Zengguang, Y., Xiaolin, D. and Meing, X. (2015). A Comparative Study on the uptake and toxicity of Nickel added in the form of different salt to maize seedlings. Intern. J. Environ. Res. Public Health.12 (1):15075-15078.

Johnson, A., Gunawardana, B., Singhal, N. (2009). Amendments for enhancing copper uptake by Brassica juncea and Lolium perenne from solution. Intern. J. of Phytorem. 11(3):215-234

Lombi, E., Zhao, FJ, Dunham, SJ, and McGrath, SP. (2001). Phytoremediation of Heavy metal contaminated soils: natural hyper accumulation versus Chemically-enhanced phytoextraction. J. of Environ. Qty 30(6): 1919-1926.

Molas, J. (2002). Changes of chloroplast ultrastructure and total chlorophyll concentration in cabbage leaves caused by excess of organic $\mathrm{Ni}$ (II) complexes, Environ. Exp. Bot., 47(2): 115 - 126.

Pandey, N. and Sharma, CP. (2002) Effect of heavy metals $\mathrm{Co}^{2+}, \mathrm{Ni}^{2+}$ and $\mathrm{Cd}^{2+}$ on growth and metabolism of Cabbage. Plant Sci. 163(4): 753-758.
Pandey, SN. and Gautam, S. (2009). Effect of nickel stress on growth and physiological responses of Trigonella foenum-graecum L. plants grown in Gomati upland alluvial soil of Lucknow. Ind. Boty. Soc. 88(1): 1-3.

Saleh, AAH. (2002). Response of Anabolic Capacities, Proline, Protein Patterns and Mineral Elements to Nickel and EDTA Stress in Chorcorus olitorius. Pak. J. of Biol. Sci. 5(4):455-460.

Senthilkumar, M., Amaresan, N., and Sankaranarayanan, A. (2021). Estimation of Proline Content in Plant Tissues. In Plant-Microbe Interactions (pp. 95-98). Humana, New York, NY.

Vajpayee, P., Rai, UN, Ali, MB, Tripathi, RD., Yadav, V., Sinha, S; Singh, SN. (2001). Chromium Induced changes in Vallisneria spiralis L.and its role in phytoremedation of tannery effluents. Bull. Environ. Toxic. 67(2): 246-256.

Yoon, J., Ca, X., Zhou, Q., Ma, L. Q. (2006). Accumulation of $\mathrm{Pb}, \mathrm{Cu}$, and $\mathrm{Zn}$ in native plants growing on a contaminated Florida site. Sci. Total Environ 368(2): 456-464

Younis, U., Athar, M., Malik, SA, Raza Shah, MH, and Mahmood, S. (2015). Biochar impact on physiological and biochemical attributes of spinach Spinacia oleracea (L.) in nickel contaminated soil. Glo. J. Environ. Sci. Manage. 1(3): 245-254.

Žarković, MB; Srdjan DB. (2009).The effects of some agrotechnical measures on the uptake of nickel by maize plants. J. of Serb. Chem. Soc., 74 (8) 10091017.

Zhou, J., Li, Z., Zhou, T., Xin, Z., Wu, L., Luo, Y., and Christie, P. (2020). Aluminum toxicity decreases the phytoextraction capability by cadmium/zinc hyperaccumulator Sedum plumbizincicola in acid soils. Sci. of the Total Environ. 711, 134591. 